\title{
Refined mapping of a gene for split hand-split foot malformation (SHFM3) on chromosome $10 \mathrm{q} 25$
}

\author{
A Raas-Rothschild, S Manouvrier, M Gonzales, J P Farriaux, S Lyonnet, A Munnich
}

\begin{abstract}
Split hand-split foot malformation (SHFM) is a genetically heterogeneous limb developmental defect characterised by the absence of digital rays and syndactyly of the remaining digits. Three disease loci have recently been mapped to chromosomes 7q21 (SHFM1), Xq26 (SHFM2), and 10q25 respectively (SHFM3). We report the mapping of SHFM3 to chromosome 10q25 in two large SHFM families of French ancestry ( $\mathrm{Zmax}$ for the combined families $=6.62$ at $\theta=0$ for marker AFM249wc5 at locus D10S222). Two recombinant events reduced the critical region to a $9 \mathrm{cM}$ interval (D10S1709D10S1663) encompassing several candidate genes including a paired box gene PAX2 $(\mathrm{Zmax}=5.35$ at $\theta=0)$. The fibroblast growth factor 8 (FGF 8), the retinol binding protein (RBP4), the zinc finger protein (ZNF32), and the homeobox genes HMX2 and HOX11 are also good candidates by both their position and their function.

( $(\mathcal{M}$ Med Genet 1996;33:996-1001)
\end{abstract}

Key words: split hand-split foot; ectrodactyly; SHFM3; chromosome 10q25.

Département de

Génétique et Unité

de Recherches sur les

Handicaps Génétiques

de l'Enfant, INSERM

U-393, Hôpital des

Enfants-Malades,

149 rue de Sèvres,

75743 Paris Cedex 15,

France

A Raas-Rothschild

$S$ Lyonnet

A Munnich

Service de Pédiatrie, Hôpital Cl Huriez, 1

Place de Verdun,

59037 Lille Cedex,

France

$S$ Manouvrier

J P Farriaux

Laboratoire

d'Embryologie

Pathologique, Hôpital

Saint-Antoine,

184 rue du

Fg Saint-Antoine,

75571 Paris Cedex 12

France

M Gonzales

Correspondence to: Dr Munnich

Received 24 June 1996 Revised version accepted for publication

4 September 1996
Split hand-split foot malformation (SHFM) is a rare developmental defect $(1 / 90000$ live births) characterised by the absence of central rays (lobster claw variety) or deficient radial rays with no cleft (monodactyly) and syndactyly of the remaining digits. ${ }^{1}$ Autosomal dominant, autosomal recessive, ${ }^{2}$ or $\mathrm{X}$ linked recessive inheritance have been reported in the disease. ${ }^{3}$ On the basis of cytogenetic abnormalities, ${ }^{4-6}$ the first locus was mapped to chromosome 7q21.3-q22.1 $\left(\mathrm{SHFM1}^{78}\right)$. A second locus has been mapped to chromosome Xq26, ${ }^{9}$ and, recently, a third locus has been mapped to chromosome 10q24-q25 (SHFM3 ${ }^{1011}$ ). By studying two large unrelated SHFM families, we support the mapping of SHFM3 to chromosome $10 \mathrm{q} 24-\mathrm{q} 25$ and reduce the genetic interval encompassing the disease gene to a region $(9 \mathrm{cM})$ where several genes, expressed during early development, have recently been localised.

\section{Families}

Eighteen affected subjects (eight males, 10 females) and 10 unaffected relatives belonging to two unrelated multigenerational SHFM families were recruited from the Service de
Pédiatrie, Hôpital Cl Huriez, Lille, France (family 1, fig 1) and the Laboratoire d'Embryologie Pathologique, Hôpital SaintAntoine, Paris, France (family 2, fig 1). Inclusion criteria were: (1) bilateral clefts of hands/feet, (2) absence of one or more digits with syndactyly of the remaining digits, and (3) no other associated osseous or visceral anomalies (fig 2). High resolution chromosomal analyses of the probands were normal (II.4, family 1, III.6, family 2 ).

Transmission of SHFM was consistent with a fully penetrant autosomal dominant mode of inheritance, with several instances of male to male transmission and no skipping of generations.

\section{Methods}

For each person, an EDTA blood sample was collected and DNA was prepared from lymphocyte pellets by SDS lysis, proteinase $\mathrm{K}$ digestion, phenol/chloroform extraction, ethanol precipitation, and Tris-EDTA resuspension. For genotyping with the polymerase chain reaction (PCR) based hypervariable microsatellite technique, ${ }^{1213}$ genomic DNA (100 ng) was submitted to PCR amplification using Taq polymerase (1 unit) in a buffer $(25 \mu \mathrm{l})$ containing $50 \mathrm{pmol}$ of each primer, $6.25 \mathrm{nmol}$ of each deoxynucleotide, $50 \mathrm{mmol} / 1 \mathrm{KCl}$, $10 \mathrm{mmol} / 1 \mathrm{Tris}-\mathrm{HCl}, \mathrm{pH} 8,1.5 \mathrm{mmol} / 1 \mathrm{MgCl}_{2}$, and $0.1 \%$ gelatin.

PCR was performed in a thermocycler (Perkin Elmer 480) with a 10 minute initial denaturation and 30 cycles of denaturation $\left(94^{\circ} \mathrm{C}\right.$, 40 seconds), annealing $\left(55^{\circ} \mathrm{C}, 40\right.$ seconds), and elongation $\left(72^{\circ} \mathrm{C}, 40\right.$ seconds), and a final elongation $\left(72^{\circ} \mathrm{C}, 10\right.$ minutes). An aliquot of amplified DNA was mixed with the loading buffer. The samples were denatured for 10 minutes at $94^{\circ} \mathrm{C}$ and loaded on a $6 \%$ polyacrylamide denaturing gel. After blotting, nylon membranes (Hybond $\mathrm{N}^{+}$, Amersham) were fixed in $0.4 \mathrm{~N}$ sodium hydroxide, hybridised with a (CA $)_{12}$ peroxidase glutaraldehyde labelled probe (Amersham ECL kit) for at least eight hours at $42^{\circ} \mathrm{C}$. Blots were washed once in a $0.3 \times \mathrm{SSC}, 0.1 \%$ SDS solution for 15 minutes, then twice in a $0.2 \times \mathrm{SSC}$ solution for 20 minutes each time and visualised using a detection solution (ECL Amersham kit) before autoradiography.

We used the Linkage package (version $5.1^{1415}$ ) to calculate lod scores (M-Link program). Two point lod scores were calculated for linkage between the disease locus and each 
Table 1 Pairwise linkage data between the SHFM3 locus and 14 polymorphic markers on chromosome $10 q$

\begin{tabular}{|c|c|c|c|c|c|c|c|c|c|}
\hline \multirow[t]{2}{*}{ Locus } & \multirow[t]{2}{*}{ Families } & \multicolumn{8}{|c|}{ Recombination fraction } \\
\hline & & 0 & 0.01 & 0.05 & 0.10 & 0.20 & 0.30 & $Z \max$ & $\theta$ \\
\hline $\begin{array}{l}\text { D10S583 } \\
\text { (AFM289zh5) }\end{array}$ & $\begin{array}{l}1 \\
2 \\
\text { Total }\end{array}$ & $\begin{array}{l}-x \\
1.28 \\
-x\end{array}$ & $\begin{array}{r}-2.13 \\
1.26 \\
-0.87\end{array}$ & $\begin{array}{r}-0.23 \\
1.16 \\
0.93\end{array}$ & $\begin{array}{l}0.41 \\
1.04 \\
1.45\end{array}$ & $\begin{array}{l}0.73 \\
0.77 \\
1.50\end{array}$ & $\begin{array}{l}0.64 \\
0.49 \\
1.13\end{array}$ & $\begin{array}{l}0.75 \\
1.28 \\
1.58\end{array}$ & $\begin{array}{l}0.2 \\
0 \\
0.16\end{array}$ \\
\hline $\begin{array}{l}\text { D10S574 } \\
\text { (AFM269zd9) }\end{array}$ & $\begin{array}{l}1 \\
2 \\
\text { Total }\end{array}$ & $\begin{array}{l}-x \\
0.96 \\
-x\end{array}$ & $\begin{array}{r}-1.93 \\
0.95 \\
-0.98\end{array}$ & $\begin{array}{r}-0.67 \\
0.88 \\
0.21\end{array}$ & $\begin{array}{r}-0.25 \\
0.78 \\
0.53\end{array}$ & $\begin{array}{r}-0.01 \\
0.55 \\
0.54\end{array}$ & $\begin{array}{l}0.01 \\
0.31 \\
0.32\end{array}$ & $\begin{array}{l}0.01 \\
0.96 \\
0.59\end{array}$ & $\begin{array}{l}0.25 \\
0 \\
0.15\end{array}$ \\
\hline $\begin{array}{l}\text { D10S1758 } \\
\text { (AFM311ze9) }\end{array}$ & $\begin{array}{l}1 \\
2 \\
\text { Total }\end{array}$ & $\begin{array}{l}-x \\
1.5 \\
-x\end{array}$ & $\begin{array}{l}0.45 \\
1.48 \\
1.93\end{array}$ & $\begin{array}{l}1.60 \\
1.39 \\
2.99\end{array}$ & $\begin{array}{l}1.89 \\
1.28 \\
3.17\end{array}$ & $\begin{array}{l}1.76 \\
1.02 \\
2.78\end{array}$ & $\begin{array}{l}1.31 \\
0.73 \\
2.04\end{array}$ & $\begin{array}{l}1.88 \\
1.5 \\
3.17\end{array}$ & $\begin{array}{l}0.15 \\
0 \\
0.10\end{array}$ \\
\hline $\begin{array}{l}\text { D10S1709 } \\
\text { (AFMb050zc5) }\end{array}$ & $\begin{array}{l}1 \\
2 \\
\text { Total }\end{array}$ & $\begin{array}{l}-x \\
-0.72 \\
-x\end{array}$ & $\begin{array}{l}2.45 \\
0.73 \\
3.18\end{array}$ & $\begin{array}{l}2.88 \\
0.74 \\
3.62\end{array}$ & $\begin{array}{l}2.83 \\
0.73 \\
3.56\end{array}$ & $\begin{array}{l}2.36 \\
0.61 \\
2.97\end{array}$ & $\begin{array}{l}1.68 \\
0.42 \\
2.10\end{array}$ & $\begin{array}{l}2.88 \\
0.74 \\
3.62\end{array}$ & $\begin{array}{l}0.05 \\
0.05 \\
0.05\end{array}$ \\
\hline $\begin{array}{l}\text { D10S198 } \\
\text { (AFM126yd6) }\end{array}$ & $\begin{array}{l}1 \\
2 \\
\text { Total }\end{array}$ & $\begin{array}{l}4.51 \\
0.22 \\
4.73\end{array}$ & $\begin{array}{l}4.45 \\
0.21 \\
4.66\end{array}$ & $\begin{array}{l}4.16 \\
0.19 \\
4.35\end{array}$ & $\begin{array}{l}3.78 \\
0.15 \\
3.93\end{array}$ & $\begin{array}{l}2.96 \\
0.09 \\
3.05\end{array}$ & $\begin{array}{l}2.04 \\
0.04 \\
2.08\end{array}$ & $\begin{array}{l}4.51 \\
0.22 \\
4.73\end{array}$ & $\begin{array}{l}0 \\
0 \\
0\end{array}$ \\
\hline $\begin{array}{l}\text { D10S192 } \\
\text { (AFM094tc9) }\end{array}$ & $\begin{array}{l}1 \\
2 \\
\text { Total }\end{array}$ & $\begin{array}{l}3.31 \\
2.11 \\
5.42\end{array}$ & $\begin{array}{l}3.26 \\
2.07 \\
5.33\end{array}$ & $\begin{array}{l}3.04 \\
1.93 \\
4.97\end{array}$ & $\begin{array}{l}2.76 \\
1.74 \\
4.50\end{array}$ & $\begin{array}{l}2.15 \\
1.33 \\
3.48\end{array}$ & $\begin{array}{l}1.46 \\
0.88 \\
2.34\end{array}$ & $\begin{array}{l}3.31 \\
2.11 \\
5.42\end{array}$ & $\begin{array}{l}0 \\
0 \\
0\end{array}$ \\
\hline PAX2 & $\begin{array}{l}1 \\
2 \\
\text { Total }\end{array}$ & $\begin{array}{l}3.91 \\
1.43 \\
5.34\end{array}$ & $\begin{array}{l}3.85 \\
1.41 \\
5.26\end{array}$ & $\begin{array}{l}3.60 \\
1.31 \\
4.91\end{array}$ & $\begin{array}{l}3.27 \\
1.27 \\
4.44\end{array}$ & $\begin{array}{l}2.56 \\
0.88 \\
3.43\end{array}$ & $\begin{array}{l}1.76 \\
0.56 \\
2.31\end{array}$ & $\begin{array}{l}3.91 \\
1.43 \\
5.34\end{array}$ & $\begin{array}{l}0 \\
0 \\
0\end{array}$ \\
\hline $\begin{array}{l}\text { D10S222 } \\
\text { (AFM249wc5) }\end{array}$ & $\begin{array}{l}1 \\
2 \\
\text { Total }\end{array}$ & $\begin{array}{l}4.51 \\
2.1 \\
6.62\end{array}$ & $\begin{array}{l}4.45 \\
2.07 \\
6.52\end{array}$ & $\begin{array}{l}4.16 \\
1.91 \\
6.07\end{array}$ & $\begin{array}{l}3.78 \\
1.70 \\
5.48\end{array}$ & $\begin{array}{l}2.96 \\
1.24 \\
4.20\end{array}$ & $\begin{array}{l}2.04 \\
0.74 \\
2.78\end{array}$ & $\begin{array}{l}4.51 \\
2.1 \\
6.62\end{array}$ & $\begin{array}{l}0 \\
0 \\
0\end{array}$ \\
\hline $\begin{array}{l}\text { D10S534 } \\
\text { (AFM198yh8) }\end{array}$ & $\begin{array}{l}1 \\
2 \\
\text { Total }\end{array}$ & $\begin{array}{r}4.51 \\
-0.44 \\
4.08\end{array}$ & $\begin{array}{r}4.45 \\
-0.41 \\
4.04\end{array}$ & $\begin{array}{r}4.16 \\
-0.31 \\
3.84\end{array}$ & $\begin{array}{r}3.78 \\
-0.23 \\
3.55\end{array}$ & $\begin{array}{r}2.96 \\
-0.11 \\
2.85\end{array}$ & $\begin{array}{r}2.04 \\
-0.05 \\
1.99\end{array}$ & $\begin{array}{r}4.51 \\
-0.05 \\
4.08\end{array}$ & $\begin{array}{l}0 \\
0.3 \\
0\end{array}$ \\
\hline $\begin{array}{l}\text { D10S1663 } \\
\text { (AFMa205wc9) }\end{array}$ & $\begin{array}{l}1 \\
2 \\
\text { Total }\end{array}$ & $\begin{array}{l}3.31 \\
-x \\
-x\end{array}$ & $\begin{array}{l}3.26 \\
0.12 \\
3.38\end{array}$ & $\begin{array}{l}3.04 \\
0.67 \\
3.71\end{array}$ & $\begin{array}{l}2.76 \\
0.79 \\
3.55\end{array}$ & $\begin{array}{l}2.15 \\
0.69 \\
2.84\end{array}$ & $\begin{array}{l}1.46 \\
0.43 \\
1.89\end{array}$ & $\begin{array}{l}3.31 \\
0.788 \\
3.72\end{array}$ & $\begin{array}{l}0 \\
0.10 \\
0.05\end{array}$ \\
\hline $\begin{array}{l}\text { D10S597 } \\
\text { (AFM331xa9) }\end{array}$ & $\begin{array}{l}1 \\
2 \\
\text { Total }\end{array}$ & $\begin{array}{l}-0.08 \\
-x \\
-x\end{array}$ & $\begin{array}{l}-0.06 \\
-0.52 \\
-0.58\end{array}$ & $\begin{array}{r}-0.02 \\
0.07 \\
0.05\end{array}$ & $\begin{array}{l}0.003 \\
0.23 \\
0.23\end{array}$ & $\begin{array}{l}0.02 \\
0.24 \\
0.26\end{array}$ & $\begin{array}{l}0.02 \\
0.13 \\
0.14\end{array}$ & $\begin{array}{l}0.02 \\
0.24 \\
0.26\end{array}$ & $\begin{array}{l}0.2 \\
0.2 \\
0.2\end{array}$ \\
\hline $\begin{array}{l}\text { D10S562 } \\
\text { (AFM259xg5) }\end{array}$ & $\begin{array}{l}1 \\
2\end{array}$ & -0.09 & -0.08 & -0.03 & 0.004 & 0.03 & 0.02 & 0.03 & 0.2 \\
\hline $\begin{array}{l}\text { D10S221 } \\
\text { (AFM249vf1) }\end{array}$ & $\begin{array}{l}1 \\
2\end{array}$ & $-x$ & -2.37 & -1.03 & -0.52 & -0.12 & 0.01 & 0.03 & 0.4 \\
\hline $\begin{array}{l}\text { D10S190 } \\
\text { (AFM065yh11) }\end{array}$ & $\begin{array}{l}1 \\
2\end{array}$ & $-\infty$ & -0.81 & 0.48 & 0.9 & 1.07 & 0.89 & 1.07 & 0.2 \\
\hline
\end{tabular}

Table 2 Summary of key recombinant events involving the SHFM3 locus and polymorphic markers on chromosome $10 q$

\begin{tabular}{llllllllll}
\hline Families & Clinical status & D10S583 & D10S574 & D10S1758 & D10S1709 & D10S198 & D10S222 & D10S1663 & D10S562 \\
\hline 1 & NA & + & + & + & - & - & - & - & - \\
1 & NA & + & - & - & - & - & - & - & - \\
1 & A & + & + & + & + & - & - & - & - \\
2 & A & - & - & - & - & - & - & + & + \\
\hline
\end{tabular}

$\mathrm{NA}=$ not affected. $\mathrm{A}=$ affected. $+=$ recombination event. $-=$ no recombination.

microsatellite marker. SHFM was tested assuming that the disease is transmitted as an autosomal dominant trait (gene frequency $\mathrm{f}=$ $1 / 10000$ with a $70 \%-100 \%$ penetrance). ${ }^{16}$

\section{Results}

As SHFM1 has been assigned to chromosome 7q21-q22, the D7S527-D7S554 interval ( $2 \mathrm{cM}$ ) encompassing the SHFM1 locus was first tested and excluded in our two families $(Z=-2.9$ at $\theta=0.02$, and $Z=-5.7$ at $\theta=$ 0.05 for loci D7S527 and D7S554 respectively, not shown). We observed linkage between the disease gene and probe AFM126yd6 at the D10S198 locus on chromosome 10q25 $(\mathrm{Zmax}=4.73$ at $\theta=0$ for the combined families 1-2) (table 1). Further pairwise linkage analyses using additional markers mapping to the same region are shown in table 1 . Assuming full penetrance the maximum lod score values for the combined families were above 3 for four markers and the highest pairwise lod score value was obtained with probe AFM249wc5 at the D10S222 locus $(Z \max =6.62$ at $\theta=0$ for the combined families 1 and 2). No significantly different results were obtained when the penetrance of the trait was allowed to vary between $70 \%$ and $100 \%(Z \max =5.71$ and $Z \max =6.62$ at $\theta=0$ at locus D10S222 for a penetrance of $70 \%$ and $100 \%$, respectively).

Results of haplotype analyses provided direct evidence of four recombination events in the two families (table 2). All recombinant meioses were informative with D10S1709. One recombinant event was observed between this locus and the disease gene (family 1, III.5) and placed the SHFM3 gene distal to the D10\$1709 locus. One recombinant event was observed between the D10S1663 locus and the disease gene (family 2, III.2) placing the SHFM3 gene proximal to D10S1663. With respect to the marker loci, all haplotypes could be resolved with a maximum of one recombination event (fig 1, table 1). These recombination events allowed us to assign the SHFM3 locus to the $9 \mathrm{cM}$ interval defined by loci D10S1709 and D10S1663 and encompassing loci D10S198, D10S192, 


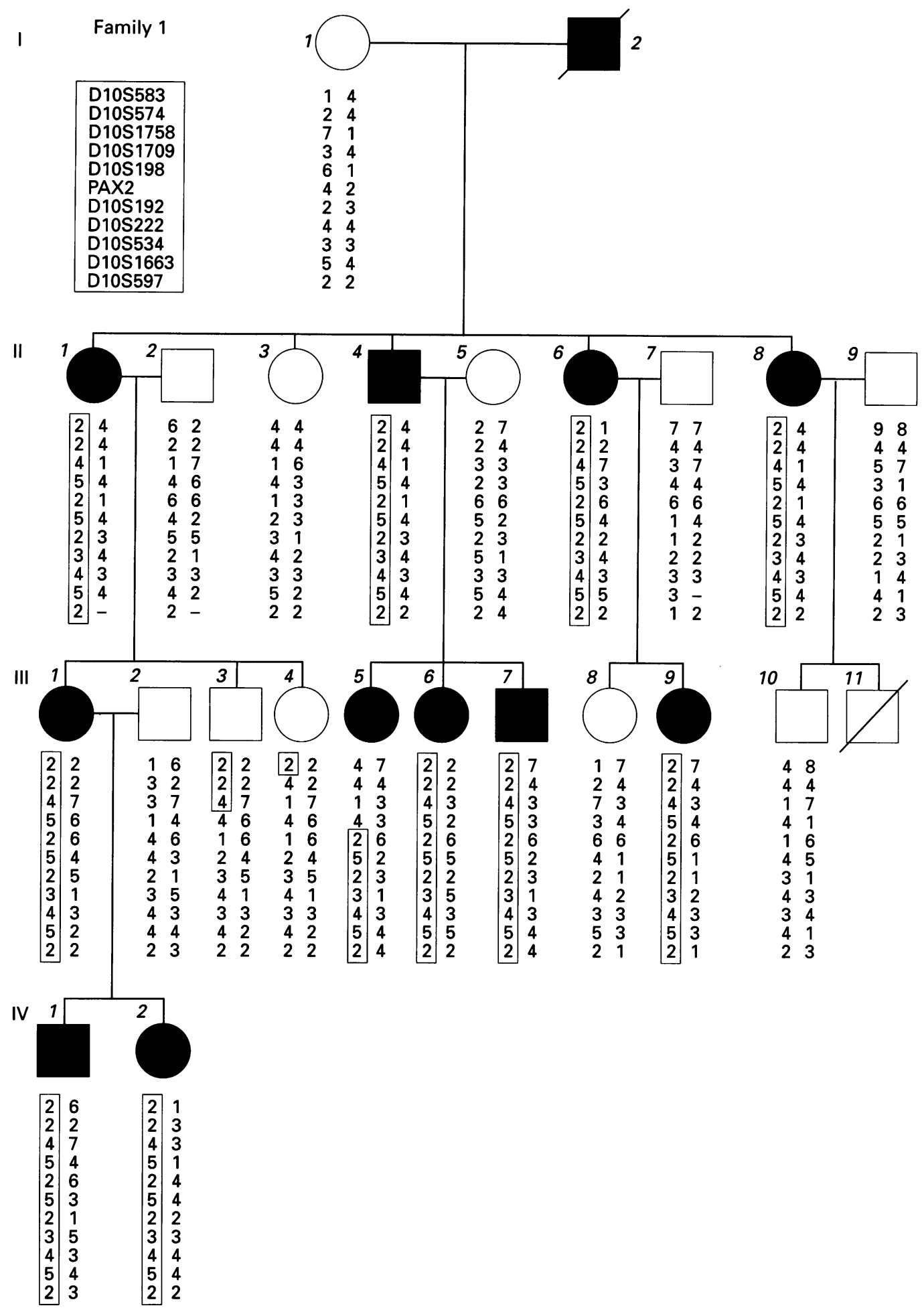

Figure 1 Pedigrees and haplotypes at the SHFM3 locus. Boxes outline common haplotypes. The Pax2 gene is located between D10S198 and D10S192 according to Gurrieri et al. ${ }^{\prime \prime}$

D10S222, and D10S534: pter-D10S583-(2)D10S574-(1)-D10S1758-(2)-D10S1709-(3)D10S198-(2)-D10S192-(1)-D10S222-(2)D10S534-(1)-D10S1663-(2)-D10S597-(6)D10S562-(2)-D10S221-(2)-D10S190-cen (with genetic distance estimate in $\mathrm{cM}$ shown in parentheses). ${ }^{13}$

Interestingly, PAX2, a human paired box protein gene mapped to chromosome 10q25 by both in situ hybridisation ${ }^{17}$ and linkage analysis in our families showed no recombination with several polymorphic markers mapping to the same interval $(\mathrm{Zmax}=6.45, \mathrm{Zmax}=7.58$, $\mathrm{Zmax}=7.88$, and $\mathrm{Zmax}=5.71$ at $\theta=0$ at loci D10S198, D10S192, D10S222, and D10S534 respectively; data not shown, available on request). A yeast artificial chromosome (YAC) positive for D10S198 and D10S192 was also consistently positive for PAX2. ${ }^{18}$ These features, along with the absence of recombinant events between PAX2 and the disease locus $(\mathrm{Zmax}=5.35$ at $\theta=0$, table 1$)$, suggest that PAX2 should be considered as a candidate gene for SHFM3. 


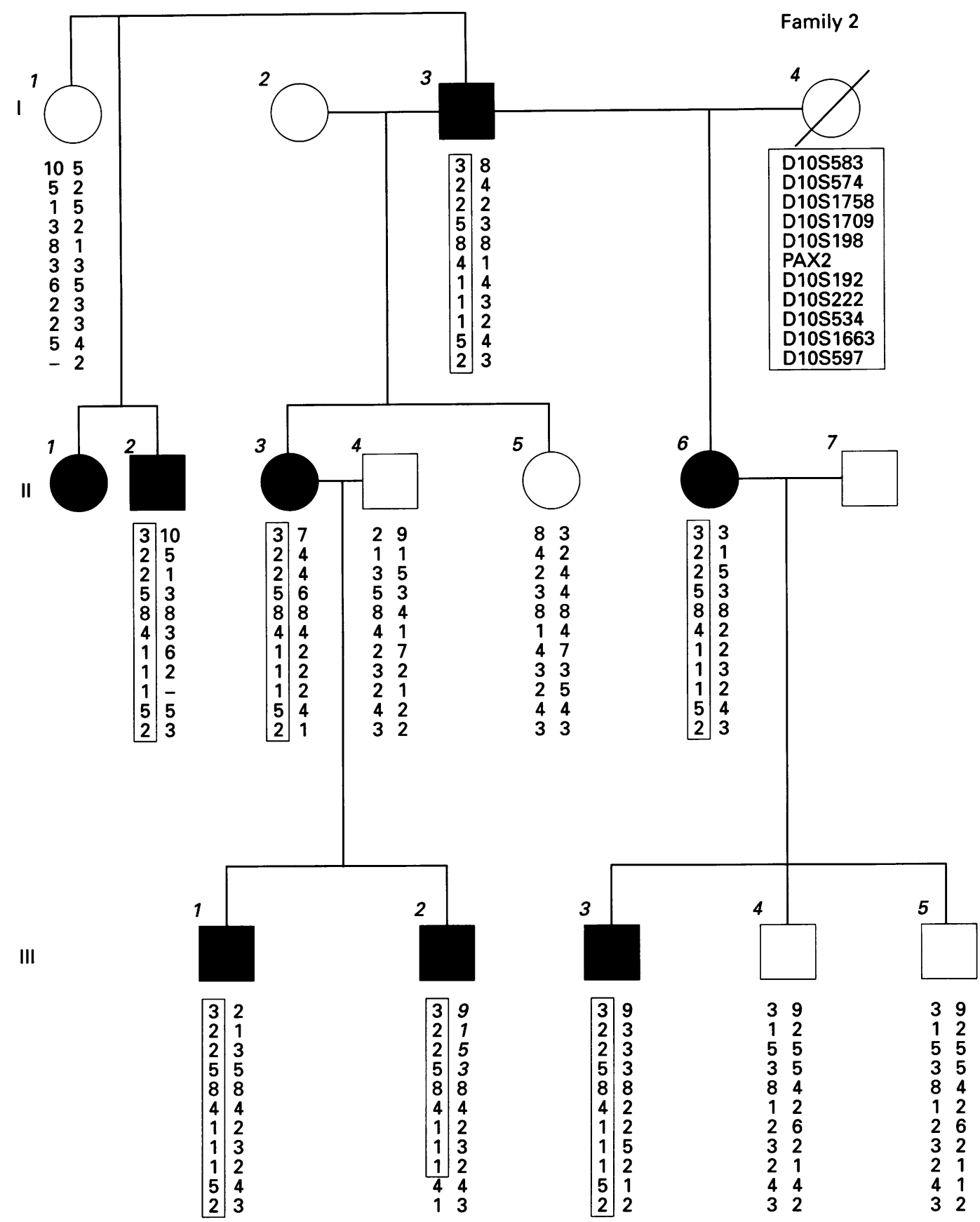

Figure 1-contd
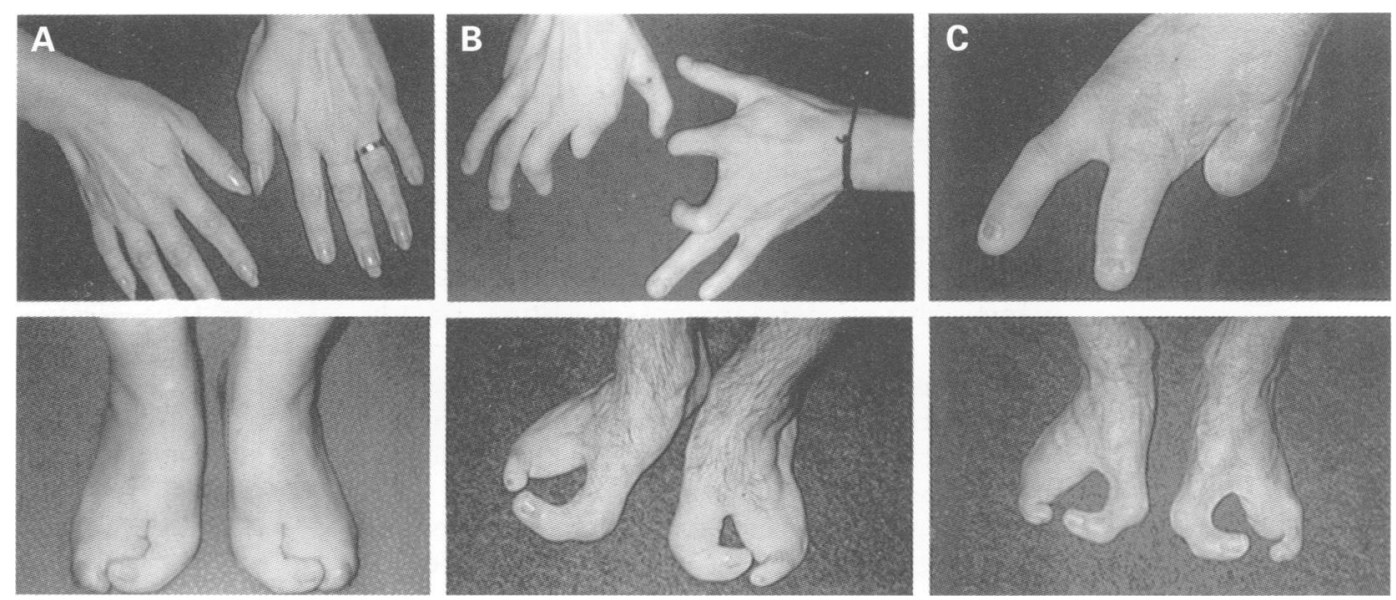

Figure 2 Intrafamilial variability of the SHFM3 phenotype in family 2. (A) Hands and feet of II.3. (B) Hands and feet of III.1. (C) Hand and feet of III.2. 


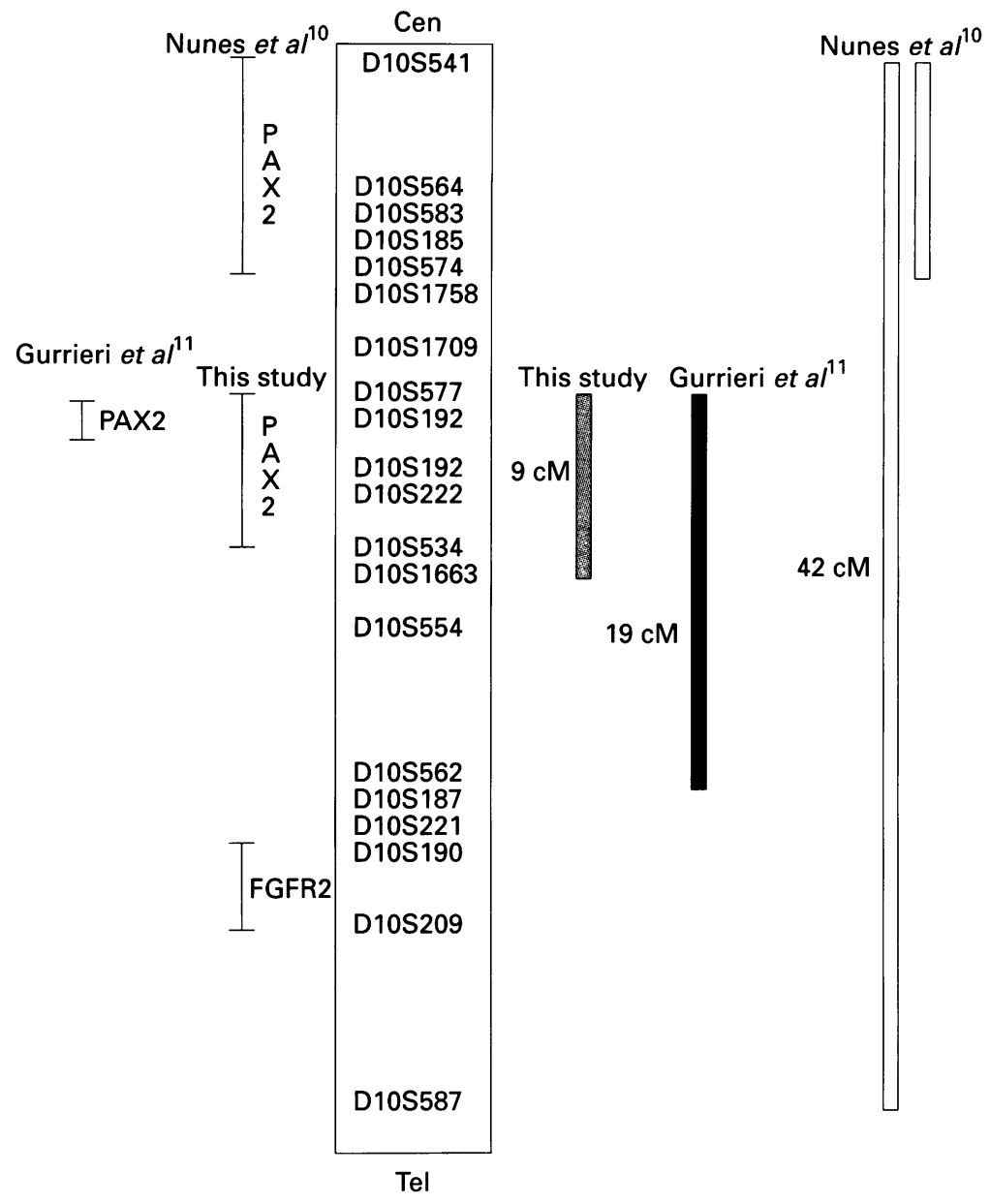

Figure 3 Delineation of the SHFM3 critical region on chromosome 10q.

\section{Discussion}

The present study supports the mapping of a gene for split hand-split foot deformity (SHFM3) to chromosome 10q24-25 in two large unrelated families of French origin. Taking advantage of two key recombinants, we were able to map the SHFM3 gene to the D10S1709-D10S1663 interval and therefore to reduce the interval encompassing the disease gene from $19 \mathrm{cM}^{11}$ to only $9 \mathrm{cM}$. This interval is included both in the D10S541-D10S587 maximal interval $(42 \mathrm{cM})$ and the D10S198D10S187 interval $(19 \mathrm{cM})$ reported by Nunes et $a l^{10}$ and Gurrieri et $a l,{ }^{11}$ respectively as the most likely genetic intervals in SHFM3 (fig 3).

This study does not rule out, however, locus heterogeneity on chromosome $10 \mathrm{q} 25$, a possibility which might account for the interfamilial variability of the malformation (fig 2). Alternatively, the variable expression of SHFM3 might involve unknown modifying genes during development, a feature already reported in the dactylaplasia mouse where the dominant mutation Dac has been mapped to a region syntenic to chromosome $10 \mathrm{q} 25$ and whose expression is modified by another locus, called mdac. ${ }^{1920}$

Interestingly, several candidate genes involved in limb development map to chromosome 10q24-25, namely the fibroblast growth factor receptor $2\left(\mathrm{FGFR2} 2^{21}\right)$, the fibroblast growth factor $8\left(\mathrm{FGF}^{22}\right)$, the paired box PAX2, the homeoboxes HOX $11^{23}$ and $\mathrm{HMX} 2,{ }^{24}$ the retinol binding protein $\mathrm{RBP} 4,{ }^{25}$ and the zinc finger protein genes $\left(\mathrm{ZNF} 32^{26}\right)$. FGFR2 which accounts for several acrocephalosyndactyly syndromes ${ }^{21}$ could be excluded as it maps outside the genetic interval reported here (fig 3). FGF8 is an interesting candidate gene in both its position and its function, as it is expressed in the apical ectodermal ridge during the early formation of the limb bud. Hitherto, however, no mutation in the coding sequence of the gene has been found in our probands (not shown).

PAX2 also should be regarded as a candidate gene by both position and function. Indeed, this transcription factor is active during early embryogenesis and no recombination with SHFM3 has been found in our two families nor in the previous reports. ${ }^{1011}$ Hitherto, however, PAX2 mutations have been associated with retinal and kidney defects, but no limb malformations have been observed in patients harbouring these particular PAX2 mutations. ${ }^{27}$ Similarly, HOX11, a homeobox gene (mapping $500 \mathrm{~kb}$ away from PAX2) involved in segmentation and branching of limb elements, and HMX2 (also mapped to 10q25) should be regarded as candidate genes for SHFM3. The characterisation of the SHFM genes will hopefully shed light on the molecular mechanisms that govern hand and foot development in the early stages of embryogenesis.

We thank Dr J Kaplan and Dr S Faure for their comments and Monique Dailhat for her help in preparing the manuscript. We gratefully acknowledge the generous support of the Fondation des Treilles, 90 rue de Varenne, 75007 Paris, France and of the Association Française contre les Myopathies (AFM).

1 McKusick VA. Mendelian inheritance in man. 10th ed. Baltimore: Johns Hopkins University Press, 1992.

2 Freire-Maia A. A recessive form of ectrodactyly and its implications in genetic counseling. $\mathcal{f}$ Hered $1971 ; 62: 53$.

3 Ahmad M, Abbas H, Haque S, Flatz G. X-chromosomally inherited split hand/split foot anomaly in a Pakistani kindred. Hum Genet 1987;75:169-73.

4 Sharland M, Patton MA, Hill L. Ectrodactyly of limbs and feet in a child with a complex translocation including 7q21.2. Am f Hum Genet 1991;39:413-14.

5 Neri G, Genuardi M, Pomponi MG, Sammito V, Zollino $M$. Further evidence for the presence of a split hand/ foot deformity gene on chromosome $7 \mathrm{q} 21$ from a family seot deformity gene on chromosome $2 ; 7$ translocation. Am $\mathcal{F}$ Hum Genet 1992; 51:A327.

6 Naritomi K, Izumikawa $Y$, Tohura T, Hirayana K. Inverted insertion of chromosome 7q and ectrodactyly. Am $\mathcal{F}$ Med Genet 1993;46:492-3.

7 Scherer SW, Poorkaj P, Massa $\mathrm{H}$, et al. Physical mapping of the human split hand/split foot (SHSF) locus on chromosome 7 and implication in syndromic ectrodactyly. Hum Mol Genet 1994;3:1345-54.

8 Scherer S, Poorkaj P, Allen T, et al. Fine mapping of the autosomal dominant split hand/split foot locus on chromosome 7, band q21.3-q22.1. Am ₹ Hum Genet 1994; 55:12-20.

9 Faiyaz UL, Haque M, Uhlhaas S, et al. Mapping of the gene for X-chromosomal split hand/split foot anomaly to Xq26-26.1. Hum Genet 1993;91:17-9.

10 Nunes ME, Schutt G, Kapur RP, et al. A second autosomal split hand/split foot locus maps to chromosome 10q24split hand/split foot locus maps to Genet 1995;4:2165-70.

11 Gurrieri F, Prinos P, Tackels D, et al. A split hand-split foot (SHFM3) gene is located at 10q24-25. Am ₹ Med Genet 1996;62:427-36.

12 Weissenbach J, Gyapay C, Dib G, et al. A second generation linkage map of the human genome. Nature 1992;359: 794-801.

13 Dib C, Faure S, Fizames C, et al. A comprehensive genetic map of the human genome based on 5,264 microsatellites. map of the human genom

14 Lathrop GM, Lalouel JM. Easy calculation of lod scores and genetic risks on small computers. Am $\mathcal{f}$ Hum Genet 1984;36:460-5.

15 Lathrop CM, Lalouel JM, Julier C, Ott J. Multilocus linkage analysis in humans. Detection of linkage and estimation of recombination. Am ₹ Hum Genet 1985;37:482-98

16 Zlotogora J. On the inheritance of the split hand/split foot malformation. Am $\mathcal{f}$ Med Genet 1994;53:29-32. 
17 Stapelton P, Weith A, Urbanek P, Kozmik Z, Busslinger N. Chromosomal localisation of seven PAX genes and cloning of a novel family member, PAX-9. Nat Genet 1993;3: 292-8.

18 Moschonas NK, Spurr NK, Mao J. Report of the first international workshop on human chromosome 10 mapping 1995. Cytogenet Cell Genet (in press).

19 Chai CK. Dactylaplasia in mouse, a two-locus model for development anomalies. F Hered 1981;72:234-7.

20 Johnson KR, Lane PW, Ward-Bailey P, Davisson M. Mapping the mouse dactylaplasia mutation, Dac, and a gene that controls its expression. Genomics 1995;29:457-64.

21 Preston RA, Post C, Keats BJB, et al. A gene for Crouzon craniofacial dysostosis maps to the long arm of chromosome 10. Nat Genet 1994;7:149-53.

22 White RA, Dowler LL, Angeloni SV, Pasztor LM, MacArthur CA. Assignment of FGF8 to human chromosome 10q25-q26: mutations in FGF8 may be responsible for some types of acrocephalosyndactyly linked to this region. Genomics 1995;30:109-11.
23 Kennedy MA, Gonzalez-Sarmiento R, Keed UR, et al. HOX11, a homeobox containing T-cell oncogene on human chromosome 10q24. Proc Natl Acad Sci USA 1991; 88:8900-4.

24 Stadler HS, Murray JC, Leysens NJ, Goodfellow PJ, Solursh M. Phylogenetic conservation and physical mapping of $M$. Phylogenetic conservation and physical mapping of
members of the H6 homeobox gene family. Mammalian members of the H6 ho

25 Rocchi M, Covone A, Romeo G, Faraonio R, Colantuoni $\mathrm{V}$. Regional mapping of RBP4 to 10q23-q24 and RBP1 to 3q21-q22 in man. Somat Cell Mol Genet 1989;15: 185-90.

26 Cannizzarro LA, Aronnson MM, Thiesen HJ. Human zinc finger gene ZNF23 (KOX16) maps to a zinc finger gene cluster on chromosome 16q22 and ZNF32 (KOX30) to chromosome 10q23-24. Hum Genet 1993;91:383-5.

27 Sanyanusin P, Schimmenti LA, Mcnoe LA, et al. Mutation of the PAX2 gene in a family with optic nerve colobomas, renal anomalies and vesicoureteral reflux. Nat Genet 1995; 9:358-63. 